INTERNATIONAL JOURNAL OF RESEARCHES IN BIOSCIENCES, AGRICULTURE AND TECHNOLOGY (C) VISHWASHANTI MULTIPURPOSE SOCIETY (Global Peace Multipurpose Society) R. No. MH-659/13(N)

\title{
A Systematic Account of the Fresh Water Diatom from Chulband River of Gondia District, Maharashtra (India). Prashant C. Shahare
}

D. B. Science College, Gondia. prashant_26184@rediffmail.com.

\begin{abstract}
:
Algae play significant ecological role and are being extensively used as indicator of water pollution because they are natural inhabitants of water. Diatoms are a major group of algae and are among the most common types of phytoplankton. Aquatic ecosystem a variety of communities, which constitute the characteristics and functioning of the ecosystem in terms of maintaining production and food chain. The quality of water determines the biological components of the aquatic ecosystem. For qualitative study of Diatoms, samples were collected at monthly intervals from Chulband River during Feb 2010 to Jan 2011. Total 21 species of diatom were identified with the help of relevant monographs \& standards literatures. In all 21 forms of Diatoms could be collected and identified which belongs to 13 Genus as Fragilaria (1), Synedra (2), Frustulia (1), Gyrosigma (2), Neidium (1), Stauroneis (2), Anomoeonies (1), Navicula (3), Pinnularia (2), Amphora (1), Cymbella (1), Hantzschia (1) and Nitzschia (2). The genus like Synedra, Navicula and Nitzschia recorded as pollution indicator in the present study but their population was very low. All the taxa were recorded for the first time form the study area and hence the presence study is focused on exploring the various diatoms flora of this River.

Keywords: Systematic, Fresh water, diatoms, Chulband River, Gondia.
\end{abstract}

\section{Introduction}

Diatoms are a major group of microscopic algae and the most common types of phytoplankton which are found in every habitat where water is present and their (both fossils and living forms) well preserved siliceous frustules / cell walls make them ideal tools for various applied applications (Stoermer \& Smol 1999). The diatom flora is diverse in fresh water bodies, brackish and marine ecosystems and one of the richest algal groups in India due to having wide range of climate, topology and natural habitats. Their abundant growth is controlled by the physicochemical conditions of water. According to You et al. (2009) their diversity depends on gradients of water, nutrients availability, $\mathrm{pH}$, temperature and altitudes of the habitats. Therefore, analysis of water has a great importance in the ecological study of diatoms. Pascher (1930) described the large number of diatoms belonging to the central and pannales group in his monograph "Die Sasswasserflora". Venkataraman $(1939,1956)$ gave a systematic account of South Indian Diatoms.

Krishnamurthy (1952) made a contribution to the diatom flora of South India. Gonzalves and Gandhi $(1952,1953)$ have given a systematic account of the diatoms of the Bombay and Salsette. Gandhi (1955, 1956, 1960, 1961) made extensive studies on the fresh water diatomaceae of India. Jena et al. (2006) reported the diatoms from Orissa state and its neighboring region. Patil and Kumawat (2007) worked on the centric diatom of Abhora Dam, Jalgaon, Maharashtra. Jadhawar and Papdiwal (2012) studied the diatom diversity of
Nath Sagar water reservoir, Maharashtra. Sarode and Kamat (1983) studied on fresh water diatoms of Vidarbha. In Gondia district Cherian and Shahare, (2011) reported 18 forms of algae of which 9 belongs to Cyanophyceae, 3 to Chlorophyceae and 6 to Bacillariophyceae were reported from Chulband River, Gondia district. Shahare and Cherian, (2012) reported 20 forms of desmids were observed from Chulband River, Gondia district. Shahare and Cherian, (2012) reported 32 forms of Cyanophyceae were observed from Chulband Dam, Gondia district. In all 21 forms of Desmids could be collected and identified which belongs to 5 Genus as Cosmarium, Euastrum, Staurastrum Micrasteria and Closterium were observed from Chulband Dam, Gondia district, Maharashtra. But no work has been done on the diatoms of Chulband River, Gondia district. Hence, the present study is an attempt to fill this gap.

\section{Materials and Methods}

A. Collection: samples were collected at monthly intervals from Chulband River during Feb 2010 to Jan 2011.

B. Identification: The algal taxa of diatoms were identified with the help of relevant monographs \& standards literatures (Desikachary, 1959; West and West, 1905; Bruhl and Biswas, 1926; Prescott, 1951; Turner, 1978; Gerrath, 2005; Coesel and Meesters,2007). All identified taxa of Diatoms were arranged taxonomically in table- 1 .

C. Site map: The map -1 \& 2 illustrate the location of Gondia District in Maharashtra State. Studied locations is shown in Table- 1. 

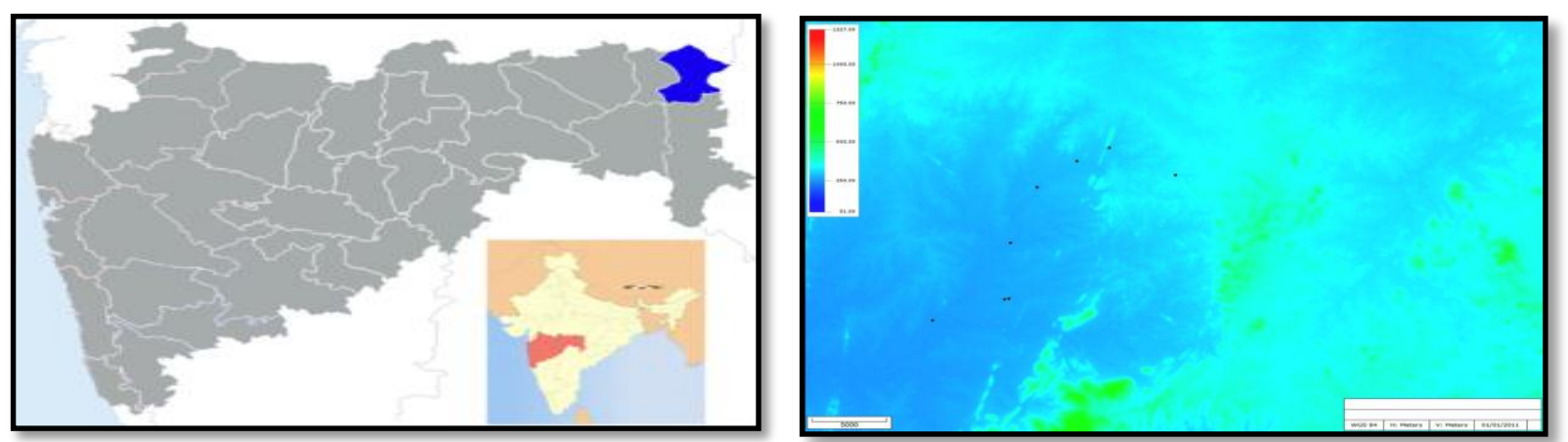

Map-1: of Maharashtra highlighting Gondia.Dist.

Map-2: Selected spot highlighting Chulband River.

\begin{tabular}{|c|c|c|c|c|}
\hline Site & Locations & Longi (E) & Latitude (N) & Alt (m) \\
\hline 1 & Jambhali & $80^{\circ} 15^{\prime \prime} 45.40^{\prime}$ & $21^{\circ} 12^{\prime \prime} 36.93^{\prime}$ & 233 \\
\hline 2 & Chulband & $80^{\circ} 13^{\prime \prime} 12.11^{\prime}$ & $21^{\circ} 14^{\prime \prime} 05.14^{\prime}$ & 310 \\
\hline 3 & $\mathrm{NH}$ & $80^{\circ} 11^{\prime \prime} 55.62 ’$ & $21^{\circ} 13^{\prime \prime} 21.90^{\prime}$ & 289 \\
\hline 4 & Murpar & $80^{\circ} 10^{\prime \prime 23.09}$ & $21^{\circ} 11^{\prime \prime} 57.86^{\prime}$ & 272 \\
\hline 5 & Bothali & $80^{\circ} 09^{\prime \prime 20.39}$ & $21^{\circ} 08^{\prime \prime} 57.10^{\prime}$ & 267 \\
\hline 6 & Sadak Arjuni-I & $80^{\circ} 09^{\prime \prime} 17.33^{\prime}$ & $21^{\circ} 05^{\prime \prime} 56.72^{\prime}$ & 269 \\
\hline 7 & Sadak Arjuni-II & $80^{\circ} 09^{\prime \prime} 06.98^{\prime}$ & $21^{\circ} 05^{\prime \prime} 55.34^{\prime}$ & 269 \\
\hline 8 & Saundad & $80^{\circ} 06^{\prime \prime} 19.30^{\prime}$ & $21^{\circ} 04^{\prime \prime} 47.58^{\prime}$ & 262 \\
\hline
\end{tabular}

Table no. 1 Locations (Lat. and Long.)

\section{Result and Discussion:}

Systematic account

1. Fragilaria capucina Desm. v. arctica A. Cl. : (Plate1-Fig. 1)

Valves 26-35 $\mu$. long, 2.9-3.5 $\mu$ broad, slender, sublinear, narrow towards the end; ends slightly constricted; psedudoraphe distinct, linear lanceolate; central area not formed; striae $16-18$ in $10 \mu$.Perceived in water bodies.

2. Synedra acus Kuetz. v. acula (Kuetz.) V. H. : (Plate1-Fig.2)

Valves 115-266 $\mu$ long, 2.8-4 $\mu$ broad, narrow, linear and needle like with slightly capitate ends ; pseudoraphe narrow ; central area without striae ; striae 16-18 in $10 \mu$, delicate.Perceived in water bodies.

3. Synedra affinis kg. (Plate1-Fig.3)

Dimensions: Length 80-115.0 $\mu$, Breadth $4.2-5.6 \mu$, Straie $12-13$ in $10 \mu$. Perceived in water bodies.

4. Synedra ulna (Nitz.) Ehr. (Plate1-Fig.4) Valves 99-136 $\mu$ long, 5.1-6.4 $\mu$ broad, linear to linear lanceolate and tapering at the ends; ends rounded; pseudoraphe narrow, linear; central area absent or present; striae $9-11$ in $10 \mu$, coarse. Perceived in water bodies.

5. Frustulia jogensis Gandhi: (Plate1-Fig.5) Valves 56-59.6 $\mu$ long, 13-13.4 $\mu$ broad, linear lanceolate with constricted, produced beak like rounded ends; raphe thin, delicate and straight, enclosed between the siliceous ribs; axial area very narrow, linear; central area small; striae about 32 in $10 \mu$, perpendicular to the middle line, finely punctate, punctate arranged in straight longitudinal rows.Perceived in water bodies

6. Gyrosigma baikalensis Skv.(Plate1-Fig.6) Valves 121-130 $\mu$ long and 16-16.4 $\mu$ broad, lanceolate, sigmoid, strongly tapering into produced and acutely rounded ends; raphe sigmoid and central; central area flexuous, small; Striae 17-18 in $10 \mu$, transverse straie slightly radial in the middle and equal in number to the longitudinal striae. Perceived in water bodies

7. Gyrosigma maharashtrensis sp. Nov. (Plate1-Fig.7)

Valves 93-103 $\mu$ long, 13-14.5 $\mu$ broad, very slightly sigmoid, linear, gradually narrowed towards the ends; ends somewhat produced and acutely rounded; raphae slightly excentric and sigmoid; axial area very narrow; central area very small elliptical; transverse striae about 30 in 10 $\mu$, very fine; longitudinal striae about 25 in $10 \mu$, faint. Perceived in water bodies

8. Neidium longiceps (Greg.) A. Cl. v. undulatum (Mayer) A. Cl. (Plate1-Fig. 8)

Valves 41-56 $\mu$ long, 9.2-12.8 $\mu$ broad, linear elliptical with very slightly triundulate margins and constricted broadly produced, feebly capitate rounded ends; raphe thin and straight with central pores bent in opposite directions; axial area very narrow; central area large, transversely elliptical; striae 22-24 in $10 \mu$, finely punctae, slightly radial, crossed by a 
faint longitudinal furrow near the margins.

Perceived in water bodies.

9. Stauroneis anceps Ehrenh. (Plate1-Fig.9) Valves 35.4-59.6 $\mu$ long, 12.5-15.6 $\mu$ broad, elliptic-lanceolate with constricted, capitate and broadly rounded ends; raphe thin, threadlike, straight with slightly curved terminal fissures; axial area narrow, linear; central area wide and stauroid, widening towards the margins; striae 22-24 in $10 \mu$, finely punctate and radial throughout. Perceived in water bodies.

Plate.1: Diatoms Flora of Chulband River, Gondia district Maharashtra.




10.Stauroneis obtuse $\boldsymbol{v}$. nagpurensis.(Plate1Fig. 10

Valves 45.5-51 $\mu$ long, 9.5-10.7 $\mu$ broad, linear, lanceolate with acutely rounded ends; polar septa well developed ; raphe straight, slightly thickened ; axial area narrow; central area wide, stauriod, more widening towards the margins; striae $14-16$ in $10 \mu$, strongly radial and distinctly punctate. Perceived in water bodies.

11.Anomoeonies sphaerophora (Kutz.) Pfit. (Plate1-Fig. 11)

Valves 46.8-69.5 $\mu$ long and 10.8-21.3 $\mu$ broad, ends rostrate subcapitate, striae about $14-18$ in $10 \mu$, punctate. Perceived in water bodies.

12.Navicula halophila (Grun.) Cleve f. robusta Hustedt. (Plate1-Fig. 12)

Valves 52-56.8 $\mu$ long, 12.2-13.4 $\mu$ broad, elliptic lanceolate with produced, slightly capitate ends; raphe somewhat thick and straight; axial area narrow; central area slightly widened; striae $17-19$ in $10 \mu$, perpendicular to the middle line.Perceived in water bodies

13. Navicula microcephala Grun(Plate1-Fig.13) Valves 15.2-18.5 $\mu$ long, 3-3.5 $\mu$ broad, narrowly lanceolate with rostrate ends; raphe thin and straight; axial area moderate; central area slightly widened; striae 25-26 in $10 \mu$, almost parallel, fine. Perceived in water bodies.

14.Navicula sacrophagus sp. nov. Gandhi (Plate1-Fig.14): Frustules rectangular in gridle view with distinct central nodules or thickening. Valves 15.6-20 $\mu$ long and 5.4$5.5 \mu$ broad, heteropolar, linear lanceolate, ends constricted obtusely rostrate rounded. Raphe thin and straight or slightly undulate with central pores distinct, somewhat closely set and terminal fissures shortly curved. Axial area very narrow, linear, central area large and rounded. Striae about 20-22 in 10 $\mu$, radial throughout, clearly punctate, punctae about $21-22$ in $10 \mu$, middle striae somewhat widely set about $16-18$ in $10 \mu$. Perceived in water bodies.

15.Pinnularia dolosa Gandhi (Plate1-Fig. 15) Valves 82-90 $\mu$ long, 14.5-14.9 $\mu$ broader, linear, tumid in the middle with slightly swollen broadly rounded ends; raphe formed in the hyaline zone, central pores closely set and unilaterally bent, terminal fissures curved; axial area wide, with fine irregularly disposed punctae; central area slightly unilaterally dilated; striae 9-11 in $10 \mu$, thick, slightly radial in the middle and convergent at the ends. Perceived in water bodies.

16. Pinnularia kiusiuensis Skv. (Plate1-Fig.16) Valves 69-77 $\mu$ long, 13.5-13.9 $\mu$ broad, linear, slightly gibbous in the middle with swollen rounded ends; raphe thick, more or less complex with central pores unilaterally bent and terminal fissures thick, curved; axial area linear, about $1 / 5-1 / 4$ the breath of the valve; central area large and unilaterally reaching the margins; striae 910 in $10 \mu$, thick, slightly radial in the middle and convergent at the ends, with longitudinal band.Perceived in water bodies.

17. Amphora veneta Kutz. (Plate1-Fig.17)

Frustules $12.6 \mu$ broad, valves 10-39 $\mu$ long and 4.7-6.5 $\mu$ broad. Striae about $11-20$ in $10 \mu$ in the middle to $24-26$ in $10 \mu$ towards ends.Perceived in water bodies.

18. Cymbella tumidula Grun. (Plate1-Fig. 18) Valves 38.5-50 $\mu$ long, 9-10.5 $\mu$ broad, asymmetrical, lanceolate, with strongly convex dorsal margin and slightly convex ventral margin; ends constricted, produced and rounded; raphae thick, excentric; axial area very narrow; central area slightly widened towards the dorsal side; ventral side with two distinct punctate; striae 10-12 $\mu$ in $10 \mu$, radial, indistinctly punctate and somewhat closer towards the ends. Perceived in water bodies.

19.Hantzschia amphioxys (Ehr.) Grun. v. gracilis Hustedt (Plate1-Fig. 19)

Valves 59-87 $\mu$ long, 7-8.9 $\mu$ broad, linear arcuate with dorsal margin convex and ventral margin concave with wedge shaped, constricted, shortly capitate ends; keel excentric with short keel punctate, 7-10 in $10 \mu$; striae $16-18$ in $10 \mu$, fine but distinctly punctate.Perceived in water bodies.

20.Nitzschia irremissa Cholnoky (Plate1Fig.20): Valves 48.2-55 $\mu$ long, 4.3-5 $\mu$ broad, narrowly lanceolate with somewhat narrowly produced, weakly capitate ends; keel very excentric, unconstricted in the middle; keel punctae 11-22 in $10 \mu$, small, rounded and somewhat irregularly set ; striae too fine for counting.Perceived in water bodies.

21.Nitzschia obtusa W. Smith v. scalpelliformis Grun. (Plate1-Fig.21)

Valves 75-129 $\mu$ long, 5.5-7.5 $\mu$ broad, linear, very slightly sigmoid with obliquely wedge shaped acutely rounded ends; keel punctae $7-8$ in $10 \mu$, large, rounded ; striae 30-32 in $10 \mu$, very fine.Perceived in water bodies. 


\section{Conclusion:}

In the present investigation, 21 diatoms (Table no.2) taxa belonging to 9 genus of Bacillariophyceae were systematically enumerated. Out of 21 taxa, The 9 genus of Bacillariophyceae were recorded of which 3 species belongs to Synedra, 3 species belongs to Navicula, and 2 each species belongs to Gyrosigma, Stauroneis and Pinnularia. 1 each species belongs to Fragilaria, Frustulia, Neidium, Anomoeonies, Amphora, Cymbella and Hantzschia. Thus the Bacillariophyceae population is represented with 21 species out of which 3 forms were of pollution indicators as per Palmer (1968) index. The Navicula and Nitzschia forms were the highest pollution indicator with 3 palmer index while Synedra forms lowest with 2 palmer index. In this present study diatom was observed dominant with Synedra, Navicula, Gyrosigma, Stauroneis and Pinnularia species. A sharp distinction in numerical population of Diatoms were clearly observed at different selected spots in Chulband River, Gondia district.

Table.2: Diatoms Flora of Chulband River, Gondia district Maharashtra.

\begin{tabular}{|c|l|c|c|c|c|c|c|c|c|}
\hline \multirow{2}{*}{ Sr. No Name of Species } & \multicolumn{5}{|c|}{ Occurrence of Diatoms } \\
\cline { 3 - 9 } & & A & B & C & D & E & F & G & H \\
\hline 1 & Fragilaria capucina Desm. v. arctica A. Cl. & - & + & + & + & + & + & + & + \\
\hline 2 & Synedra acus Kuetz. v. acula (Kuetz.) V. H. & + & - & - & + & + & + & + & + \\
\hline 3 & Synedra affinis kg. & + & + & - & - & + & + & + & + \\
\hline 4 & Synedra ulna (Nitz.) Ehr.Amphoraveneta Kutz. & - & - & + & + & + & + & + & + \\
\hline 5 & Frustulia jogensis Gandhi & - & + & - & + & + & + & + & - \\
\hline 6 & Gyrosigma baikalensis Skv. & + & - & - & - & + & - & - & - \\
\hline 7 & Gyrosigma maharashtrensis sp. Nov. & - & - & + & + & + & - & - & + \\
\hline 8 & Neidium longiceps (Greg.) A. Cl. v. undulatum & - & - & - & - & + & + & + & - \\
\hline 9 & Stauroneis anceps Ehrenh. & - & - & + & + & + & + & + & + \\
\hline 10 & Stauroneis obtuse v. nagpurensis. & - & + & - & - & + & + & + & - \\
\hline 11 & Anomoeonies sphaerophora (Kutz.) Pfit. & - & - & - & - & + & - & - & - \\
\hline 12 & Navicula halophila (Grun.) Cleve f. robusta & + & + & + & + & + & + & + & + \\
\hline 13 & Navicula microcephala Grun. & - & + & + & + & + & + & + & + \\
\hline 14 & Navicula sacrophagus sp. nov. Gandhi & + & - & - & + & + & + & + & + \\
\hline 15 & Pinnularia dolosa Gandhi & - & + & - & + & + & + & + & + \\
\hline 16 & Pinnularia kiusiuensis Skv. & + & - & - & + & + & + & + & + \\
\hline 17 & Amphora veneta Kutz. & - & + & - & + & - & - & - & - \\
\hline 18 & Cymbella tumidula Grun. & - & + & - & - & + & + & + & + \\
\hline 19 & Hantzschia amphioxys (Ehr.) Grun. v. gracilis & - & - & + & + & + & + & + & + \\
\hline 20 & Nitzschia irremissa Cholnoky & + & - & + & + & + & + & + & + \\
\hline 21 & Nitzschia obtusa W. Smith v. scalpelliformis Grun. & + & - & - & - & + & + & + & + \\
\hline
\end{tabular}

\section{References}

Cherian K.J. and Shahare P.C; "Pollution, a threat to conservation of biodiversity in fresh water body of Chulband river, Gondia dist., Maharashtra" Essence, Volume II No. 2 [70 78]. (2011).

Coesel, P.F.M. and K. Meesters,; Desmids of the Lowlands. KNNV Publishing, Zeist, Netherlands. (2007).

Desikachary TV; Cyanophyata. ICAR, New Delhi. 4. (1959).

Gandhi, H. P.; A Contribution to our knowledge of the freshwater Diatoms of Pratapgarh, Rajasthan. J. Indian Bot. Soc., 34: 307. (1955).

Gandhi, H. P.; A Contribution to the Knowledge of freshwater Diatomaceae of South-Western India. J. Indian Bot. Soc., 35:194. (1956).

Gandhi, H. P.; The Diatom flora of the Bombay and Salsette Island. J. Bom. Nat. Hist. Soc., 57: 78-123. (1960).

Gandhi, H. P.; Notes on the Diatomaceae from Ahmedabad and its environs. Hydrobiol., 17 : 218-236. (1961).
Gerrath J.F.; Conjugating Green Algae and Desmids. In: Freshwater Algae of North America: Ecology ard Classification, Wehr, J.D. and R.G. Sheath (Eds.). Academic Press, USA., pp: 353381. (2005).

Gonzalves, E. A. and Gandhi, H. P.; A systematic account of the Diatoms of Bombay and Salsette. I. J. Indian Bot. Soc., 31: 117-151. (1952).

Gonzalves, E. A. and Gandhi, H. P.; A systematic account of the Diatoms of Bombay and Salsette. II. J. Indian Bot. Soc., 32: 239-263. (1953).

Jadhawar, P. B. and Papdiwal, P. B.; Taxonomic diversity of diatom at Nath Sagar Water reservoir, Paithan, Maharashtra. The Ecoscan, 6: 1-4. (2012).

Jena, M., Ratha, S. K. and Adhikary, S. P.; Diatoms (Bacillariophyceae) from Orissa state and neighbouring regions, India, Algae, 21: 377392. (2006). 
Krishnamurthy, V. A; Contribution to the diatom flora of South India. J. Indian Bot. Soc., 33 (4): 354-381. (1952).

Narayan, P., Barupal, G. K., College, G. D., and Rajasthan, B.; Research Article A Systematic Account of the Fresh Water Diatom from Kaylana Lake of Jodhpur District , Rajasthan ( INDIA ), 6 , 3435-3439. (2015).

Pascher, A.; Die Sussawasser flora (Diatomeae). Volume-10. Jena Verlag von Gustav Fischer. (1930).

Patil, S. B. and Kumawat, D. A.; Studies on the centric diatoms from Abhora dame of Jalgaon District, Maharashtra. Research link. 359 (9): 154-155. (2007).

Prescott G.; Algae of the Western Great Lakes Area. Cranbook Institute of Science, Boomfield Hills, Michigan. (1951).

Sarode, P. T. and Kamat, N. D.; The Diatom flora of Vidarbha, India I. Bibliotheca Phycologica. J. Cramer., 66: 259-319. (1983).

Shahare, P. C. and Cherian K. J; "Study of Cyanophycean diversity at Chulband Dam, Gondia Dist.(M.S.), India." Bionano Frontier, Special Issue-9 (128-130). (2012).

Shahare, P. C. and Cherian K. J; Desmid flora of Chulband River, Gondia district, Maharashtra (India). Bionano Frontier, Vol. 5 (2-II), 263-268. (2012).

Stoermer F. and Smol J.P.; The diatoms: Applications for the environmental and earth sciences. Cambridge University Press, Cambridge, U.K, pp.1-466. (1999).

Turner, W.B.; Freshwater Algae of East India (Principally Desmidieae) of East India. Bishen Shingh Mahendra Pal Singh Publication Dehrudun, India. (1978).

Venkataraman, G.; A systematic account of some South Indian Diatoms. Proc. Indi. Acad. Sci., 10: 293-368. (1939).

Venkataraman, G.; Contribution to our knowledge of freshwater Diatoms of South India. Govt. Press, Madras, pp-20 (1956).

West W. and G.S. West; A Monograph of the British Desmidiaceae-II Adlard and Son, London. (1905). Bruhl, P. and K. Biswas; Algae of the Lotak Lake. Mem. Asiat Soc. Bengal, 8:257-316. (1926).

You Q, Liu Y, Wang $\mathbf{Y}$ and Wang Q.; Taxonomy and distribution of diatoms in the genera Epithemia and Rhopalodia from the Xinjiang Uygur Autonomous Region, China. Nova Hedwigia 89(3-4): 397-430. (2009). 